\title{
İşbirlikli Öğrenmenin Şarkı Söyleme Becerileri Üzerindeki Etkisi *
}

\section{Sermin BİLEN**, Kamile ÜN AÇIKGÖZ***}

Öz: Bu çalışmanın amacı işbirlikli öğrenme yönteminin şarkı söyleme becerileri üzerindeki etkisini araştırmaktır. Araştırma deseni; yarı deneysel modellerden ön test-son test eşleştirilmiş kontrol gruplu deney desenidir. Araştırma, İzmir Tınaztepe Eşrefpaşa İlkokulu 4. sınıflardan oluşan üç grup üzerinde gerçekleştirilmiştir. Rastlantısal olarak sınıflardan biri deney, diğer ikisi kontrol grubu olarak belirlenmiştir. Deney grubunda işbirlikli öğrenme yönteminin birlikte öğrenme tekniği ile müzik eğitimi yapılırken, kontrol gruplarından birisinde nota ile müzik öğrenme, diğerinde ise kulaktan notalı müzik öğretimi yapılmıştır. Veriler şarkı söyleme becerilerine ilişkin gözlem formu ile toplanmıştır.

Araştırmanın başlıca sonuçları şu şekildedir: İşbirlikli öğrenme yöntemi, nota ile öğrenme ve kulaktan notalı öğretim yöntemlerine göre şarkı söyleme becerilerinin geliştirilmesinde anlamlı düzeyde daha etkilidir. Nota ile öğrenme yöntemi ise kulaktan notalı öğretim yöntemine göre şarkı söyleme becerilerinin geliştirilmesinde anlamlı düzeyde daha etkilidir.

Anahtar sözcükler: İşbirlikli öğrenme, müzik eğitimi, şarkı öğretim yöntemleri, şark1 söyleme becerisi.

\section{The Effects of Cooperative Learning on the Singing Skills}

Abstract: The aim of this study is investigating the effect of the cooperative learning method on singing skills. In this research, the quasi-experimental design: the matching-only pretest-posttest control group desig nused. The research was carried out on three groups studying at Izmir Tinaztepe Eşrefpaşa Primary School in the 4th classes. One experimental and two control groups randomly gathered from these classes. In the experimental group,

\footnotetext{
* Bu çalışma birinci yazarın “İşbirlikli Öğrenmenin Müzik Öğretimi ve Güdüsel Süreçler Üzerindeki Etkileri” adlı doktora tez çalışmasının bir bölümünden üretilmiştir.

${ }^{* *}$ Dr. Öğr. Üyesi Dokuz Eylül Üniversitesi, Buca Eğitim Fakültesi, Güzel Sanatlar Eğitimi Bölümü, Müzik Eğitimi Anabilim Dalı, orcid no:sermin.bilen@deu.edu.tr

${ }^{* * *}$ Prof. Dr. Dokuz Eylül Üniversitesi, Buca Eğitim Fakültesi, Eğitim Bilimleri Bölümü, Eğitim Programları ve Öğretim Anabilim Dalı, orcid no:bilisegitim@gmail.com

Gönderim:21.12.2018 Kabul:19.03.2019 Yayın:20.05.2019
} 
musicteaching was carried out with the cooperative learning method. One of the control groups learned music with the notes, and the other group one learned music with the note and ear. The data collected with the singing skills observation form.

The main results of the researchare as follows: the cooperative learning method is significantly more effective in improving the sing skills compared to the learning with the note and the teaching from the ear. The learning with note method is significantly more effective in enhancing the singing skills compared to the teaching from the ear.

Keywords: Cooperativelearning, musiceducation, songteachingmethods, singingskills.

\section{Giriş}

Sanat, insanın içinde doğup büyüdüğü toplumsal ve kültürel bir çevrenin önemli bir olgusu olup, insanlığın ilk oluşumu ile gelişmeye başlayarak insanın toplumsallaşmasında ve kendini aşmasında önemli bir araç olmuştur (Billet, 1966: 52). Kendini aşmaya çalışan ve tüm insan olmak isteyen birey, bireysel yaşamın kopmuşluğundan kurtulma ve daha anlamlı bir yaşama geçme çabasındadır (Fisher, 1974: 9). Sanat eğitimi bu çabayı destekleyen önemli bir etmendir ve insan yaşamını estetik açıdan zenginleştirir. Bunun için bireyin sanatsal olarak eğitilmesi toplumsal açıdan da önemli bir değer taşır.

Müzik, sanatın etkili dallarından biridir. Eflatun, ince bir müzik duyarlığının uygarlığa en çok yaklaştıran bir eğitim aracı olduğundan söz etmektedir. Müziğin verdiği ince duygularla arınmış bir hayal ve müzikle eğitilmiş bir zihninin günlük ilişkilerde kaba kalamayacağını vurgulamaktadır (Edman, 1977: 58-59).

Müziğin bir eğitim aracı olabilmesi okullardaki verilmekte olan müzik derslerindeki öğrenme-öğretme sürecinin etkili öğrenme yöntemleri ve teknikleri ile yönlendirilmesine bağlıdır. Öğrencilerin yaratıcı ve müzikal potansiyellerinin geliştirilmesi, kendilerini müzikal olarak ifade edebilmeleri; öğrencilerin öğrenme sürecine aktif katılımlarının sağlanacağı ve öğretmenin rehber olduğu aktif öğrenme yöntemleri ile olanaklıdır. Dalcroze, Kodaly, OrffSchulwerk ve Gordon Müziği Öğrenme Teorisi öğrencilerin öğrenme sürecine aktif olarak katıldıkları ve öğretmenin rehber rolü üstlendiği çağdaş müzik eğitimi yaklaşımlarının başında gelir (Labuta ve Smith, 1997: 108-116). Günümüzde etkililiği süren ve dünyanın gelişmiş ülkelerinin vazgeçilmez eğitim rehberini oluşturan bu yaklaşım ve yöntemlerin ortak yönleri, bilgilerin ezberlenmediği müziğin dinamiklerinin içselleştirildiği, öğrenmeyi öğrenmenin öğretildiği, öğretmenin lider değil rehber rolü üstlendiği bir süreç içerisinde gerçekleştirilmesidir. 
Sözü edilen çağdaş müzik eğitimi yaklaşımları ile aktif öğrenme yöntemlerinden biri olan işbirlikli öğrenme yönteminin eğitim felsefeleri birçok yönden örtüşmektedir. Ezberlemeden bilgilerin keşfedilmesine dayalı öğrenme süreci, üründen çok sürecin ön plana geçmesi, öğretmenin rehber rolü üstlenmesi, grup üyelerinin katkıları ile ürün ortaya koyma gibi eğitim felsefelerini yansıtan birçok yön, bu yaklaşım ve yöntemlerin ortak yönünü oluşturur. Türkiye'de, eğitimin değişik alanlarında yer almakla birlikte 1995 yılına kadar müzik eğitimi araştırmaları ve uygulamalarında rastlanmayan işbirlikli öğrenme Açıkgöz (1994: 4) tarafından şöyle tanımlanmaktadır: "Rastlantısal olarak oluşturulacak öğrenci gruplarındaki öğrencilerin ortak amaç doğrultusunda hem kendilerinin hem de gruptaki diğer öğrencilerin öğrenmesini en üst düzeye çıkarma çabalarına dayalı öğrenmedir.”

İşbirlikli öğrenme yöntemi, temel felsefesi aynı olmakla birlikte uygulanış biçiminde farklılıklar olan çeşitli tekniklerden oluşmaktadır. Kagan tarafından geliştirilen "işbirliğiişbirliğił", Jonson ve Jonson tarafından geliştirilen "birlikte öğrenme” ve "akademik çelişki”, Eliot Aranson ve meslektaşları tarafından geliştirilen "birleştirme" işbirlikli öğrenme yöntemi tekniklerinin başlıcaları arasında sayılabilir (Sharan, 1999: 50).

Bu tekniklere ek olarak işbirlikli öğrenme yöntemini Türkiye'ye kazandıran ve birçok araştırmaya öncülük eden Açıkgöz $(1992,64)$ tarafından "birlikte soralım birlikte öğrenelim” tekniği geliştirilmiştir.

“Birlikte Öğrenme” tekniğini geliştiren Jonson ve Jonsonişbirlikli öğrenme yönteminin uygulanışında öğretmenin izleyeceği yolu şöyle sıralamaktadır:

1. Dersin amaçlarını belirlemek.

2. Grup sayısına karar vermek, rol ve materyal dağılımı yapmak ve sınıfı düzenlemek.

3. Görevleri, pozitif bağımlılıkları, başarı için kriterleri ve beklenen sosyal becerileri açıklamak.

Öğretmen, çalışma grupları başladıktan sonra sistematik olarak gözlem yapar ve her grubun çalışmaları ile ilgili veri toplar. Grup üyelerinin görevlerini birlikte etkili biçimde tamamlamaları için araya girer ve yardım eder. Öğretmen, performansları değerlendirirken öğrenciler, grup üyeleri ile çalışma sürecinin etkili olup olmadığını değerlendirirler (Sharan, 1999: 51-53).

Açıkgöz’ün (1994) işbirlikli öğrenme tanımından hareketle işbirlikli müzik öğrenme; öğrencilerin rastlantısal oluşturulan gruplar içinde ortak amaçlar doğrultusunda çalıştıkları, grup üyelerinin birbirlerinin müzik bilgi ve becerilerini kazanmalarından sorumlu oldukları, yaratıcı potansiyellerinin gelişmesinin desteklendiği bir öğrenme süreci olarak tanımlanabilir. 
İşbirlikli müzik öğrenme sürecinde öğrenciler;

- Rastlantısal oluşturulan gruplar içinde ortak amaçlar doğrultusunda çalışırlar.

- Müzik bilgilerini, öğrenme sürecine aktif katılımları sırasında içselleştirdikleri müzikal davranışlar aracılığı ile keşfederler.

- Grup ürünü oluşturma aşamasında yaratıcı potansiyellerinin gelişmesi rehber rolü üstlenen öğretmen tarafından desteklenir.

- Çalıştıkları grup içerisinde birbirlerinin müzik bilgi ve becerilerini kazanmalarından sorumlu olurlar.

- Kendilerini müzikal olarak ifade edebilme firsatı yakalarlar.

Bilen (1995) ve Kocabaş'ın (1995) doktora tezleri Türkiye'de müzik eğitiminde işbirlikli öğrenme araştırmalarının ilklerini oluşturmuştur. Sonraki yıllarda Söker (1998), Uysal (2004), Selçioğlu (2005), Güven (2011), Öztürk (2012), Sözen (2012), Gürpınar (2014) ve Karaarslan (2015) araştırmalarında müzik eğitiminin farklı konularını işbirlikli öğrenme bağlamında ele almışlardır.

Ülkelerin gelişmişlik açısından düzeyleri ne olursa olsun, müzik ders programlarında müzik yapılan araçların en başında insan sesi yer almaktadır. İnsan sesinin müzik eğitimi araçlarının başında yer alması, müzik yapmaya yarayan diğer araçlara oranla daha doğal, pratik, ucuz, belli bir düzeye kadar eğitiminin daha kolay olmasından kaynaklanmaktadır. Ayrıca insan sesinin dil ile birleşerek daha etkin, bu etkinliğiyle bir toplumun temellerine kadar inebilecek nitelikte olması, çok sayıda insan topluluklarına müzik yapabilme olanağı sağlaması yönlerinden büyük bir güç ve önem kazanmasına neden olmaktadır. Bu nedenle de müzik sınıfları, toplu ses eğitimi için en uygun alanlardan biridir (Egüz, 1991: 103). Şark1 söyleyebilme becerisini geliştirecek olan sınıf ortamındaki ses eğitimi çalışmalarının toplu şarkı söyleme geleneğine katkısının yanı sıra bir bakıma bu katkının doğal sonucu sayılabilecek bireyin duygusal ve sosyal gelişimine de doğrudan etkisi vardır. Bu açıdan bakıldığında sınıflarda çocuklara sesini sevdirecek, müzik dersine karşı olumlu tutum geliştirecek, sınırlı ders saatlerinde onların şarkı söyleme becerilerini geliştirebilecek farklı stratejilere gereksinim duyulmaktadır. Bu gereksinim doğrultusunda bu araştırmada, işbirlikli müzik öğrenme ${ }^{1}$, nota

\footnotetext{
${ }^{1}$ İşbirlikli Müzik Öğrenme: Öğrencilerin rastlantısal oluşturulan gruplar içinde ortak amaçlar doğrultusunda çalıştıları, grup üyelerinin birbirlerinin müzik bilgi ve becerilerini kazanmalarından sorumlu oldukları, yaratıcı potansiyellerinin gelişmesinin desteklendiği bir öğrenme sürecidir.
} 
ile öğrenme ${ }^{2}$ ve kulaktan notalı öğretim ${ }^{3}$ yöntemlerinin şarkı söyleme becerilerinin geliştirilmesi üzerindeki etkileri araştırılmak istenmiştir. Bu bağlamda araştırmanın problem cümlesi şöyle ifade edilmiştir:

İşbirlikli öğrenme, nota ile öğrenme ve kulaktan notalı öğretim yöntemlerinin şark1 söyleme becerilerinin gelişmesi üzerindeki etkileri nelerdir?

\section{Yöntem}

\section{Araştırma Deseni}

$\mathrm{Bu}$ araştırmada yarı deneysel modellerden ön test-son test eşleştirilmiş kontrol gruplu deney deseni kullanılmıştır. Eşleştirilmiş desende hazır gruplardan ikisi belli değişkenler üzerinden eşleştirilmeye çalışılarak gruplar, işlem gruplarına seçkisiz atanmaktadır. Desen, deney öncesinde ön testin verilmesine ya da verilmemesine göre düzenlenmektedir (Büyüköztürk vd., 2014: 208).

\section{Araştırma Grubu}

Araştırma grupları, İzmir Tınaztepe Eşrefpaşa İlköğretim okuluna 1994-1995 öğretim yılının birinci yarıyılına devam eden 4. sınıf öğrencilerinden oluşmuştur. Araştırmanın deney grubunda işbirlikli öğrenme yöntemi tekniklerinden birlikte öğrenme ile müzik öğretimi, kontrol gruplarından birisinde nota ile müzik öğretimi, diğerinde ise kulaktan notalı müzik öğretimi gerçekleştirilmiştir. İşbirlikli öğrenme ve nota ile öğrenme gruplarındaki dersler araştırmacı tarafından, kulaktan notalı öğretim grubundaki dersler ise eğitim düzeyi, öğretmenlik deneyimi, yaş ve cinsiyet yönlerinden araştırmacıya denk olan başka bir araştırmacı tarafından yürütülmüştür.

\section{Deney Süreci}

Deney ve kontrol gruplarında on iki haftalık ders sürecinde; tartım, ezgi, vuruş kavramları, dörtlük ve sekizlik ses süreleri ile susları, ikilik ses süresi, iki dörtlük ve dört dörtlük ölçüler, dizek kavramı ve sol anahtarı, re-la beşlisi içindeki sesler, nüans terimlerinden mezzoforte, piano ve forte öğretilmiştir. Her üç grupta da aynı şarkılar ve materyaller kullanılmıştır. Her dersin başında öğrencilerin seslerini eğitmenin temelini oluşturacak nefes ve ses alıştırmaları yapılmıştır. Sınıfta ses bütünlüğü oluşturabilmek ve doğru ve güzel şarkı

\footnotetext{
${ }^{2}$ Nota İle Öğrenme: Müzik bilgilerinin öğrenilmesinde "müzikten bilgiye gitmek" ilkesinin temel alındığı, şarkıların notalarının ritmik ve ezgisel olarak öğrencilerin çözümlemelerini kolaylaştıracak stratejileri içeren bir öğrenme sürecidir.

${ }^{3}$ Kulaktan Notalı Öğretim: Bilgilerin ezberlendiği, şarkıların notalarının öğretmeni taklit ederek ezbere söylendiği bir öğretim sürecidir.
} 
söylemenin temel davranışlarını (oturuş, nefes, artikülasyon, dinleme, bağırmadan söyleme) oturtabilmek için ilk dört hafta şarkılar notasız, kulaktan öğretilmiştir.

Kulaktan notalı öğretim yönteminin kullanıldığı kontrol gruplarından birinde, konular önce anlatılmış, sonra öğrencilerin defterlerine yazdırılmıştır. Şarkılar notaları ile önce öğretmen tarafından seslendirilmiş, öğrenciler öğretmeni taklit etmişlerdir.

Nota ile öğrenme yönteminin kullanıldığı kontrol gruplarından ikincisinde, müzikle ilgili kavramların şarkı aracılığıyla hissettirilmesi yoluyla öğrencilerin bilgileri keşfetmeleri için rehberlik edilmiştir. Şarkının notaları, ses süreleri ve yükseklikleriyle öğretmenin rehberliğinde öğrenciler tarafindan çözümlenmiştir.

İşbirlikli müzik öğrenme yönteminin kullanıldığı deney grubunda ise, şarkıların nota ile öğrenilmesi aşamasında nota ile öğrenme yöntemi kullanılmıştır. Kontrol gruplarıyla sınıf dersi yapılmasına karşın deney grubunda rastlantısal oluşturulan gruplarla işbirlikli öğrenmenin ilkeleri doğrultusunda çalışılmıştır. Bilgilerin müzik aracılığıyla keşfedilmesi, şarkıların notalarının çözümlenerek solfej okunması ve şarkıların sözleriyle doğru ve güzel söylenmesi sürecinde grup üyeleri birbirlerinin öğrenmelerinden sorumlu olmuşlar, öğretmen ise lider değil, rehber rolü üstlenmiştir.

\section{Veri Toplama Araçları}

Araştırmanın verileri, araştırmacılar tarafından geliştirilmiş olan "şarkı söyleme becerilerine ilişkin gözlem formu" ile toplanmıştır. Gözlem formu, vücut pozisyonu ve esnekliği, nefes, temiz söyleme, ses bütünlüğü, tempo, tını, nüans, sözcüklerin artikülasyonu ile ilgili davranışları yansıtan 12 maddeden oluşmuştur. Ses eğitimi uzmanlarının görüşlerine başvurulmasının ardından form 8 maddelik son halini almıştır. Pilot uygulama İzmir Murat Reis İlkokulu 5. sınıfta okuyan 36 öğrenci ile yapılmıştır. Uygulamanın puanlamasını yapan 2 gözlemcinin arasındaki korelasyon hesaplama sonucu .98’dir.

\section{Verilerin Toplanması}

İşbirlikli öğrenme yöntemi tekniklerinden "birlikte öğrenme” tekniğinin kullanıldığ1 araştırma sürecinde şarkı söyleme becerilerinin temel davranışları sayılabilecek beş kritik davranış belirlenmiştir:

1. Doğru oturma(vücut dik, kaslar rahat, ayaklar dengeli ve tabana basarak).

2. Doğru yerde doğru nefes alma(şarkının belirlenmiş yerlerinde, diyaframa nefes alarak).

3. Sözcükleri iyi artiküle etme (sesli ve sessiz harfleri iyi duyurarak ve doğru vurgulayarak). 
4. Bağırmadan söyleme.

5. Birbirlerini dinleyerek söyleme.

Rastlantısal beşer kişilik gruplar oluşturulmuştur. Her bir kritik davranışın denetleme rolü grup üyeleri arasında dağıtılmıştır. Önceki derslerde öğrenilmiş bir şarkı üzerinden çalışmaları için bir süre verilmiştir. Grup üyelerinin, yukarıda belirlenen güzel şarkı söyleyebilmenin temel davranışlarının şarkıya yansıtılmasında birbirlerinden sorumlu oldukları belirtilmiştir. Ayrıca, grupların şarkıyı seslendirmeleri sırasında ritmik ve ezgisel hata yapmamaları konusunda özenli olmalarının gerekliliğine dikkat çekilmiştir.

Öğretmen grupların çalışmalarına rehberlik etmiştir. Grupların şarkı söyleme becerilerinin değerlendirilmesinde, gözlem formunda her bir kritik davranış için belirlenen puanlar kullanılmıştır. Grupların ortak ürün olarak şarkıyı seslendirmelerinin değerlendirilmesinde gözlem formuna dayalı olarak alınan puanlar; 41-50 arası çok iyi, 31-40 arası iyi, 21-30 arası iyice, 11-20 arası orta, 0-10 arası ise az iyi olarak belirlenmiştir.

Nota ile müzik öğrenme yöntemi süreci, ritmik ve ezgisel çözümlemelere dayalı olarak bilgilerin öğrenciler tarafından keşfedilmesini ve seslerin yüksekliklerinin düşünülmesini sağlayan stratejileri içerir. Kulaktan notalı müzik öğretimi ise ritmik ve ezgisel çözümlemeleri içermeyen, bilgilerin hazır verildiği taklide dayalı bir öğretim sürecidir.

Şarkı söyleyebilme becerisinin gelişmesi ile ilgili hem deney grubunda hem de kontrol gruplarında her ders nefes, vücut yumuşaklığı-rahatlı̆̆ ve dil-konuşma ögeleri ele alınmıştır. Doğru oturuş, doğru yerde doğru nefes alma, şarkının sözcüklerini doğru artiküle etme ve bağırmadan, birbirlerini dinleyerek söyleme gibi ses eğitiminin temel davranışlarına önem verilmiştir. Bu davranışların gelişmesi için dersler; nefes, ses açma ve konuşma alıştırmaları ile desteklenmiştir.

\section{Bulgular}

Grupların şarkı söyleyebilme becerisine ilişkin deney öncesi gözlem sonuçları Tablo 1'de verilmiştir.

Tablo 1. Grupların şarkı söyleme becerilerine ilişkin deney öncesi başarı durumları

\begin{tabular}{lcc}
\hline \multicolumn{1}{c}{ Gruplar } & $\overline{\mathrm{x}}$ & SS \\
\hline İşbirlikli Öğrenme $(\mathrm{n}=40)$ & 4.17 & 4.27 \\
\hline Nota ile Öğrenme $(\mathrm{n}=39)$ & 5.59 & 5.80 \\
\hline Kulaktan Notalı Öğretim $(\mathrm{n}=38)$ & 7.42 & 6.27 \\
\hline
\end{tabular}


Tablo 1'de görüldüğü gibi şarkı söyleyebilme becerisine ilişkin deney öncesi gözlem puanları ortalamalarına bakıldığında en yüksek ortalama "kulaktan notalı ögretim" grubunda en düşük ortalama ise "işbirlikli öğrenme” grubuna aittir.

Grupların başlangıçtaki şarkı söyleme becerileri arasında önemli farklılıklar olup olmadığına bakmak amacı ile deney öncesi gözlem puanları kullanılarak varians çözümlemesi yapılmıştır. Varians çözümlemesi sonuçları Tablo 2'de yer almaktadır.

Tablo 2. Grupların şarkı söyleme becerilerine ilişkin deney öncesi gözlem puanlarına göre yapılan varians çözümlemesi sonuçları

\begin{tabular}{cccccl}
\hline VK & SD & KT & KO & F & Önem Denetimi \\
\cline { 1 - 4 } GA & 2 & 212.31 & 106.15 & & \\
\cline { 1 - 4 } GI & 115 & 3464.46 & 30.39 & 3.49 & FarkÖnemli* \\
\cline { 1 - 3 } GENEL & 117 & 3676.78 & & & \\
\hline F= 3.49, $<<.05$ & & & &
\end{tabular}

Tablo 2'de görüldüğü gibi, varians çözümlemesi sonucu elde edilen F değeri 3.49'dur. Tablodaki Fdeğeri ise 3.07'dir. Bu sonuçlara göre hesaplanan F değeri, tablodaki değerinden büyük olduğu için grupların deney öncesi şarkı söyleme becerileri arasında önemli farklılıklar olduğu söylenebilir.

Şarkı söyleyebilme becerisi yönünden hangi gruplar arasında önemli farkl1l1klar olduğunu ortaya koymak için Scheffe testi yapılmıştır. Scheffe testi sonuçları Tablo 3'te verilmiştir.

Tablo 3. Grupların şarkı söyleme becerilerine ilişkin deney öncesi puanlarına göre yapılan Scheffe testi sonuçları

\begin{tabular}{|c|c|c|}
\hline Gruplar & $\begin{array}{l}\text { İşbirlikli } \\
\text { Öğrenme }\end{array}$ & $\begin{array}{cc}\text { Nota ile } & \text { Kulaktan Notalı } \\
\text { Öğrenme } & \text { Öğretim } \\
\end{array}$ \\
\hline \multicolumn{3}{|l|}{ İşbirlikliÖğgrenme(n= 40, $\bar{X}=4 . I 7)$} \\
\hline \multicolumn{3}{|l|}{ Nota ile Öğrenme $(n=38, \bar{X}=5.59)$} \\
\hline Kulaktan Notalı Öğretim $(n=40, \bar{X}=7.42)$ & Fark Önemli* & \\
\hline
\end{tabular}


Scheffe testi sonuçlarına göre deney öncesi şarkı söyleyebilme becerisi yönünden, kulaktan notalı öğretimin uygulandığı grup ile işbirlikli öğrenmenin uygulandığı grup arasında önemli fark vardır.

Grupların deney sonrasındaki şarkı söyleme becerilerinde farklılıklar olup olmadığına hazırlık olması amacıyla deney sonrası uygulanan gözlem puanları ortalamalarına bakılmıştır. Grupların deney sonrası gözlem puanları ortalamaları ve standart sapmaları tablo 4'te verilmiştir.

Tablo 4. Grupların şarkı söyleme becerilerine ilişkin deney sonrası gözlemdeki başarı durumları ( $\overline{\mathrm{X}}, \mathrm{SS})$

\begin{tabular}{lcc}
\hline \multicolumn{1}{c}{ Gruplar } & $\overline{\mathrm{X}}$ & SS \\
\hline İşbirlikli Öğrenme $(\mathrm{n}=40)$ & 35.90 & 8.58 \\
\hline Nota ile Öğrenme $(\mathrm{n}=39)$ & 28.56 & 5.51 \\
\hline Nota ile Kulaktan Öğretim $(\mathrm{n}=40)$ & 16.77 & 8.47 \\
\hline
\end{tabular}

Tablo 4'te yer alan sonuçlara bakıldığında şarkı söyleme becerilerine ilişkin deney sonrası gözlemdeki en yüksek ortalamanın işbirlikli öğrenmenin uygulandığı gruba, en düşük ortalamanın ise kulaktan notalı öğretimin uygulandığı gruba ait olduğu görülmektedir. Nota ile öğrenmenin uygulandığı grupta ise ortalamanın işbirlikli öğrenme grubundan düşük, kulaktan notalı öğretim grubundan yüksek olduğu görülmektedir.

Grupların deney sonrasındaki şarkı söyleme becerileri arasındaki farkın önemli olup olmadığına bakmak amacıyla gruplara deney öncesi ve sonrasına uygulanan şarkı söyleme becerilerine ilişkin gözlem puanlarına göre Kovariyans çözümlemesi yapılmıştır. Kovariyans çözümlemesi sonuçları tablo 5'te verilmiştir.

Tablo 5. Grupların şarkı söyleme becerilerine ilişkin deney öncesi ve sonrası uygulanan gözlem puanlarına göre yapılan Kovariyans çözümlemesi sonuçları

\begin{tabular}{ccccccc}
\hline Gözlemin Ad1 & VK & KT & sd & KO & F & $\begin{array}{c}\text { Önem } \\
\text { Denetimi }\end{array}$ \\
\hline Şarkı Söyleme & Kovarite & 2960.550 & 1 & 2960.550 & 87.830 & Fark Önemli* \\
\hline
\end{tabular}




\begin{tabular}{llcccc} 
Becerilerine & Ana etkiler & 9381.981 & 2 & 4690.991 & 139.167 \\
\cline { 2 - 5 } İlişkin Gözlem & Açılanan & 10417.054 & 3 & 3472.351 & 103.014 \\
\cline { 2 - 5 } Kalan & 3775.243 & 112 & 33.708 & \\
\cline { 2 - 5 } & Toplam & 14192.302 & 115 & 123.411 &
\end{tabular}

$$
\mathrm{F}=103.014, \mathrm{p}<.05
$$

Tablo 5'te görüldüğü gibi Kovariyans çözümlemesi sonucu elde edilen F değeri 103.708'dir. Tablodaki F değeri ise 2.68'dir. Kovariyans çözümlemesi sonucuna göre elde edilen F değeri tablodaki F değerinden büyüktür. Bu sonuç, grupların deney sonrasında şarkı söyleme becerilerinde önemli farklılıklar olduğunu göstermektedir.

Deney sonrasında şarkı söyleyebilme becerisi yönünden hangi gruplar arasında önemli farklılıklar olduğunu ortaya koymak amacıyla grupların deney sonrasındaki şarkı söyleme becerilerine ilişkin gözlem puanlarına göre Scheffe testi yapılmıştır. Scheffe testi sonuçları Tablo 6'da verilmiştir.

Tablo 6. Grupların şarkı söyleyebilme becerisine ilişkin deney sonrası gözlem puanlarına göre yapılan Scheffe testi sonuçları

\begin{tabular}{llll}
\hline \multicolumn{1}{c}{ Gruplar } & $\begin{array}{c}\text { Kulaktan Notal } \\
\text { Öğretim }\end{array}$ & $\begin{array}{c}\text { Nota ile } \\
\text { Öğrenme }\end{array}$ & $\begin{array}{c}\text { İşbirlikli } \\
\text { Ögrenme }\end{array}$ \\
\hline Kulaktan Notalı Öğretim & & \\
\hline Nota ile Öğrenme & FarkÖnemli $*$ & \\
\hline İşbirlikli Öğrenme & FarkÖnemli $*$ & FarkÖnemli* \\
\hline$*(\mathrm{p}<.05)$ & &
\end{tabular}

Tablo 6'da görüldüğü gibi Scheffe testi sonuçlarına göre işbirlikli öğrenmenin uygulandığı grupla nota ile öğrenmenin ve kulaktan notalı öğretimin uygulandığg gruplar arasında, nota ile öğrenmenin uygulandığı grupla da kulaktan notalı öğretimin uygulandığg grup arasında şarkı söyleme becerileri yönünden anlamlı düzeyde (.05) farklılıklar vardır.

Sonuç olarak denilebilir ki işbirlikli öğrenme yöntemi, nota ile öğrenme ve kulaktan notalı öğretim yöntemlerine göre, şarkı söyleyebilme becerisinin geliştirilmesinde anlamlı düzeyde daha etkilidir. Nota ile öğrenme yönteminin ise işbirlikli öğrenme yöntemi kadar etkili olmamakla birlikte, kulaktan notalı öğretim yönteminden anlamlı düzeyde daha etkili olduğu söylenebilir.

\section{Sonuç, Tartışma ve Öneri}

Araştırmanın sonuçları şu şekilde sıralanabilir: 
1. İşbirlikli öğrenme yöntemi, nota ile öğrenme ve kulaktan notalı öğretim yöntemlerine göre şarkı söyleme becerilerinin geliştirilmesinde anlamlı düzeyde daha etkilidir.

2. Nota ile öğrenme yöntemi, kulaktan notalı öğretim yöntemine göre şark1 söyleme becerilerinin geliştirilmesinde anlamlı düzeyde daha etkilidir.

Her üç araştırma grubunda da aynı konuların işlenmesi, öğrencilerin aynı ses eğitiminden geçirilmelerine rağmen şarkı söyleme becerileri açısından işbirlikli öğrenme lehine gruplar arası anlamlı farklılıkların oluşu şu nedenlerden kaynaklanabilir:

Nota ile öğrenme ve kulaktan notalı öğretim yöntemleri ses eğitiminin gereklerini yerine getirmesine rağmen yöntemlerin yapısı her öğrenci ile tek tek ilgilenmeye olanak tanımamaktadır. İşbirlikli öğrenme ise küçük grup çalışmaları ile grup üyelerinin birbirlerine yardımlarını olanaklı kılarak her öğrencinin ses eğitimi ile ilgili etkinliklere aktif olarak katılmasına ortam hazırlamaktadır. Ayrıca grup üyelerinin şarkı söyleme becerilerinin kritik davranışlarını denetleyici rolü üstlenmeleri ve işbirlikli öğrenme yönteminin temel ilkelerinden biri olan olumlu bağımlılık; şarkı söyleme becerilerinin gelişmesinde etken olmuş olabilir. Aynı sonuca, bu araştırmanın sonrasında gerçekleştirilen Uysal'ın (2004) araştırmasında da ulaşılmıştır. İlkokul düzeyinde yapılan bu araştırmanın sonuçlarından biri, işbirlikli öğrenmenin şarkı söyleme becerisi üzerinde etkili olduğu yönündedir. Sesleri, ritmi ve yüksekliği ile nasıl çözümleyeceklerine ilişkin ipuçları vererek bir bakıma öğrenmeyi öğreten bir özellik taşımaktadır. Bu özellik kulaktan notalı öğretim yöntemine göre müziksel işitme becerisinin gelişmesinde daha etkili bir ortam yaratmış olabilir. Şarkı söylemenin temeli ise şarkılarda ritmik yanlışlar yapmadan seslerin temiz söylenmesi üzerine kurulmaktadır. Böylece nota ile öğrenme yöntemi, kulaktan notalı öğretim yöntemine göre müziksel işitme becerisinin gelişmesinde daha etkili olma özelliği ile şarkı söyleyebilme becerisinin gelişmesine temel oluşturmuş olabilir.

Dünyanın çeşitli yerlerinde birçok alanda, ilköğretimden yükseköğretim düzeyine kadar yapılan araştırma bulguları işbirlikli öğrenmenin etkili bir yöntem olduğunu ortaya koymaktadır. (Açıkgöz, 1992: 78-80). Üniversite düzeyinde müzik alanında ki bir diğer araştırmanın bulguları da işbirlikli öğrenme yönteminin etkili olduğu yönündedir (Bilen, 2010).

Araştırmanın sonuçları doğrultusunda şunlar önerilebilir:

Şarkı söyleme çocukların özgüven gelişiminde önemli etkenlerden biri olduğu söylenebilir. Müzik öğretmenleri kalabalık sınıflarda her öğrenciye ulaşmakta güçlük çekebileceğinden şark1 söyleme becerilerinin gelişmesinde işbirlikli öğrenme yönteminden yararlanabilir. 
Müzik öğretmenleri için müzik eğitiminde işbirlikli öğrenme yöntem ve tekniklerine ilişkin hizmet içi eğitim programları düzenlenebilir.

Müzik eğitiminde işbirlikli öğrenme yönteminin tek bir tekniği ile sınırlı kalınmaması, aynı tip uygulama biçiminden kaynaklanabilecek tek düzeliği önleyebilir.

Çeşitli işbirlikli öğrenme yöntemi tekniklerinin yanı sıra müzik eğitiminde aktif öğrenme yaklaşımlarına ve yöntemlerine yer verilmesi; her öğrencinin kendi öğrenme hızında kendisini müzikal olarak ifade edebilmesinde yararlı olabilir.

Müzik eğitiminde işbirlikli öğrenme tekniklerinin çalgı çalma becerisi, müzik beğenisi ve yaratıcılığın geliştirilmesi üzerindeki etkileri araştırılabilir.

\section{Makalenin Bilimdeki Konumu}

Güzel Sanatlar/ Müzik Eğitimi ABD

\section{Makalenin Bilimdeki Özgünlüğü}

Makalede, işbirlikli öğrenme yönteminin şarkı söyleme becerileri üzerindeki etkisi yarı deneysel modellerden ön test-son test eşleştirilmiş kontrol gruplu deney deseni ile araştırılarak sunulmuştur. Araştırmanın yapıldığı tarih itibariyle müzik eğitiminde işbirlikli öğrenmeye ilişkin olarak Türkiye'de yapılan ilk çalışmalardan biri olma özelliğini taşımaktadır.

\section{Kaynaklar}

Bilen, S. (1995). İşbirlikli ögrrenmenin müzik öğretimi ve güdüsel süreçler üzerindeki etkileri. Doktora tezi, Sosyal Bilimler Enstitüsü Dokuz Eylül Üniversitesi, İzmir.

Bilen, S. (2010). TheEffect of Cooperative Learning on the Ability of Prospect of Music Teachers to Apply Orff-Schulwerk. World Conference on Education Sciences (4-8 Şubat 2010). İstanbul: Bahçeşehir Üniversitesi.

Billiet, J. (1966). Sosyal Oluşum ve Sanat. Çev: Mehmet Doğan. İzmir: Kovan Kitabevi.

Büyüköztürk, Ş., Kılıç Çakmak, E., Akgün, Ö. E., Karadeniz, Ş., Demirel, F. (2014). Bilimsel Araştırma Yöntemleri. Ankara: Pegem Akademi Yay.

Edman, I. (1977). Sanat ve Insan Estetiğe Giriş. Çev. Turhan Oğuzkan. 2. Bask1. İstanbul. Egüz, S. (1991). Toplu Ses Eğitimi I Temel Konular. Ankara: Ayyıldız Matbaası.

Fisher, E. (1974). Sanatın Gerekliliği. Çev. Cevat Çapan. İstanbul: Konuk Yayınları.

Gürpınar, E. (2014). İşbirlikli öğrenme yöntemine dayalı çoksesli solfej uygulamalarının müziksel işitme-okuma-yazma ve koro ders başarılarına etkisi. Doktora tezi, Eğitim Bilimleri Enstitüsü İnönü Üniversitesi, Malatya. 
Güven, E. (2011). Kaynaştırma uygulamasının yapıldı ̆̆ sınıflarda işbirlikli öğrenmenin müzik ögrretimi üzerindeki etkileri. Doktora tezi, Eğitim Bilimleri Enstitüsü Gazi Üniversitesi, Ankara.

Karaarslan, T. (2015). İşbirlikli öğrenmenin ilkokul 4.sınıf müzik dersinde ögrrencilerin ritim becerileri ve özyeterlilik algıları üzerine etkileri. Yüksek lisans tezi, Eğitim Bilimleri Enstitüsü Dokuz Eylül Üniversitesi, İzmir.

Kocabaş, A. (1995). İşbirlikli öğrenmenin blok flüt öğretimi ve ögrenme stratejileri üzerindeki etkileri. Doktora tezi, Eğitim Bilimleri Enstitüsü Dokuz Eylül Üniversitesi, İzmir.

Labuta, J. A. ve Smith, D. A. (1997). Music Education: Historical Context and Perspectives. USA: Prentice-Hall, Inc.

Öztürk, G. (2012). Müziksel işitme eğitiminde kullanılan “işbirlikli öğrenme yöntemi”nin ögrrenci kaygı ve başarısına etkisi. Doktora tezi, Eğitim Bilimleri Enstitüsü, Abant İzzet Baysal Üniversitesi, Bolu.

Selçioğlu, E. (2005). Çoklu zekâ kuramına dayalı işbirlikli öğrenmenin müzikte erişi ve hatırda tutma üzerindeki etkileri. Yüksek lisans tezi, Eğitim Bilimleri Enstitüsü, Dokuz Eylül Üniversitesi, İzmir.

Sharan, S. (1999). Handbook of Cooperative Learning Methods. USA: Praeger.

Söker, S. (1998). Işbirlikli (ortak çalışma yoluyla) öğretmenin şarkı öğretimine etkileri. Yüksek lisans tezi, Fen Bilimleri Enstitüsü, Marmara Üniversitesi, İstanbul.

Sözen, İ. (2012). İşbirlikli öğrenme yaklaşımı ile yapılan toplu bağlama öğretiminin performans ve tutuma etkisi. Doktora tezi, Eğitim Bilimleri Enstitüsü, Abant İzzet Baysal Üniversitesi, Bolu.

Uysal, G. (2004). İlköğretimde işbirlikli öğrenmenin müzik ögrretiminde sınıf atmosferi ve şarkı söyleme becerileri üzerindeki etkisi. Yüksek lisans tezi, Eğitim Bilimleri Enstitüsü, Dokuz Eylül Üniversitesi, İzmir.

Ün Açıkgöz, K. (1992). İşbirlikli Öğrenme. Kuram-Araştırma-Uygulama. Malatya: Uğurel Matbaası.

Ün Açıkgöz, K. (1994, Eylül). Tarih derslerinde öğrencileri güdüleme stratejileri. Sözel Bildiri, Tarih Öğretimi ve Ders Kitapları Buca Sempozyumu, (Yay. Haz.: Salih Özbaran, 1995). İstanbul: Tarih Vakfı Yayınları.

\section{Summary}

\section{Statement of the Problem}


Regardless of the level of development in the countries, the human voice is the basis of the instruments made music in the musicless on programs. It stems from more natural, practical, in expensive and more accessible to educate compared to othere musical instruments. The voice education activities in the classroom environment improve the singing ability and affect the motional and social development of the individual. From this point of view, different strategies needed that it is necessary to develop a positive attitude towards musicless on sand to develop a different attitude towards the lesson.

Therefore, it was aimed to investigate the effects of the cooperative learning method, learned music with the note method and teaching music with the note and ear method on the singing skills. In this context, the problem statement of the research expressed as follows: What are the effects of cooperative learning method, learned music with the note method and teaching music with the note and ear method on the singing skills?

\section{Method}

In this research, the quasi-experimental design: the matching-only pretest-posttest control group design used. The research was carried out on three groups studying at Izmir Tinaztepe Eşrefpaşa Primary School in the 4th classes in the 1994-1995 academic year, first semester.

One experimental and two control groups randomly gathered from these classes. In the experimental group, music teaching was carried out with the cooperative learning method. One of the control groups learned music with the notes, and the other group learned music with the note and ear.

The data collected with the singing skills observation form. For the evaluation of the groups' singing skills; the singing skills observation form used which developed by researchers. The form has eight items reflecting behavior about body posture and flexibility, breathing, voiceunity, clearly singing, tempo, timbre, nuance, articulation of the wors.

\section{Findings}

Mean, standard deviation, variance analysis and Scheffe test results of the research are as follows:

- The cooperative learning method is significantly more effective in improving the sing skills compared to the learning with the note and the teachingfrom the ear.

- The learning with note method is significantly more effective in improving the singing skills compared to the teaching from the ear.

\section{Discussionand Conclusion}


Although the same subjects were studied and the same voice training used in the experimental and control groups, there are significant differences between groups in favor of cooperative learning. These reasons may cause it:

Although learned music with the note method and teaching music with the note and ear method fulfill the requirements of voice training, the structure of the methods does not allow each student to be interested in one by one. On the other hands, the cooperative learning method process enables the group members to help each other with small group work and provide the opportunity for each student to participate in activities related to voice education actively. Besides, group members play a supervisory role in the critical behavior of singing skills and positive dependence which one of the basic principles of cooperative learning may have contributed to the development of singing skills.

Learned music with the note method has a property which taught how can learn like the cooperative learning method. For this reason, it may have created a more effective environment than teaching music with the note and ear method. 